F. Reprod. Fert. (1967) 13, 579-581

BRIEF COMMUNICATION

\title{
CHROMOSOME ABNORMALITIES IN EARLY EMBRYOS OF THE PIG
}

\author{
RICHARD A. McFEELY \\ Department of Clinical Studies, School of Veterinary Medicine, University of Pennsylvania
}

(Received 17th December 1966)

This report presents the results of chromosome analysis of blastocysts collected and processed as previously described (McFeely, 1966) from seven gilts selected at random from the swine herd at the University of Pennsylvania. No records of parentage of the gilts were available, but as they consisted of various breeds and cross breeds from a variety of sources, it was assumed that they were not closely related. Two unrelated, pure bred, Yorkshire boars were used as sires. Chromosome analysis of peripheral blood leucocytes from all of the pigs did

TABLE 1

CHROMOSOME ANALYSIS OF 10-DAY BLASTOCYSTS

\begin{tabular}{|c|c|c|c|c|c|c|c|}
\hline Gilt & $\begin{array}{l}\text { No. of } \\
\text { corpora } \\
\text { lutea }\end{array}$ & $\begin{array}{c}\text { Noo. of } \\
\text { blastocysts }\end{array}$ & $\begin{array}{c}\text { Cells } \\
\text { analysed }\end{array}$ & $\begin{array}{l}\text { Cells with } \\
\text { modal } \\
\text { chromosome } \\
\text { No. }\end{array}$ & $X r$ & $X X$ & Abnormalities \\
\hline $\mathrm{J}_{\mathbf{P}}$ & $\begin{array}{r}8 \\
12\end{array}$ & $\begin{array}{r}8 \\
12\end{array}$ & $\begin{array}{l}93 \\
81\end{array}$ & $\begin{array}{l}69 \\
77\end{array}$ & $\begin{array}{l}3 \\
3\end{array}$ & $\begin{array}{l}4 \\
7\end{array}$ & $\begin{array}{l}\text { Triploid XXX } \\
\text { Deletion SM group; tetraploid } \\
\text { XXYY }\end{array}$ \\
\hline $\begin{array}{l}\mathrm{Q} \\
\mathrm{T} \\
\mathrm{U}\end{array}$ & $\begin{array}{l}10 \\
16 \\
13\end{array}$ & $\begin{array}{l}10 \\
16 \\
12\end{array}$ & $\begin{array}{r}48 \\
133 \\
60\end{array}$ & $\begin{array}{r}44 \\
131 \\
52\end{array}$ & $\begin{array}{l}7 \\
8 \\
4\end{array}$ & $\begin{array}{l}2 \\
7 \\
6\end{array}$ & $\begin{array}{l}\text { Triploid XYY } \\
\text { Degenerating } \\
\text { Tetraploid XXYY degenera- }\end{array}$ \\
\hline $\begin{array}{l}\mathrm{w} \\
\mathrm{x}\end{array}$ & $\begin{array}{l}12 \\
19\end{array}$ & $\begin{array}{l}12 \\
18\end{array}$ & $\begin{array}{l}104 \\
154\end{array}$ & $\begin{array}{l}101 \\
147\end{array}$ & $\begin{array}{l}5 \\
8\end{array}$ & $\begin{array}{l}6 \\
7\end{array}$ & $\begin{array}{l}\text { Triploid XXY } \\
\text { Triploid XXX; diploid } \mathrm{XX} / \\
\text { triploid XXX; tetraploid } \\
\text { XXX }\end{array}$ \\
\hline Total & 90 & 88 & 673 & 621 & 38 & 39 & \\
\hline
\end{tabular}

not reveal any abnormalities, nor were any physical defects observed in the animals. No immunization or drugs were administered at any time during the experiment, and no disease of consequence was noted.

The recovery rate of blastocysts was $98 \%$ based on corpora lutea counts as indicative of the number of ova shed (Perry \& Rowlands, 1962). The chromosome analyses, summarized in Table 1 , showed that $10 \%$ of the blastocysts collected from normal healthy pigs possessed grossly detectable chromosome defects. In addition, $2.3 \%$ were already apparently degenerating as evidenced by the absence of mitotic figures and the great preponderance of pycnotic cells. Lethal chromosome combinations cannot be excluded as a cause of cell death in these degenerating blastocysts. 
The ultimate influence of chromosome abnormalities on the viability of the affected blastocysts is unknown, but the association of similar defects with human spontaneous abortion is quite apparent (Carr, 1963). As these kinds of changes have not been reported in living pigs, it is assumed that at least some of them are associated with embryonic death. If they are not, then one would expect them to be present in about the same ratio in the normal population.

Triploidy can arise by several mechanisms. Fertilization of an ovum in which release of either polar body has been suppressed will result in two sets of maternal chromosomes and one set of paternal chromosomes. The sex chromosomes are of value in interpreting anomalies of this type, because, while the XXX blastocysts could have arisen in this matter, clearly the XYY ones could not. However, fertilization of an ovum with two spermatozoa could account for both combinations. Fertilization of an ovum with a diploid spermatozoon seems an unlikely possibility.

Tetraploidy arises most commonly from failure of the first cleavage division, but could arise theoretically by such accidents as fertilization of an ovum by three spermatozoa or by double fertilization of an ovum with a suppressed polar body. The complexity of the latter mechanisms, if they exist at all, limits serious consideration. In the former mechanism it is apparent that there will be two sets of chromosomes of maternal origin and two of paternal origin, and that the sex chromosomes much be either XXXX or XXYY. The tetraploids in this study are all of these types and support the theory that they arose by suppression of the first cleavage division.

The diploid/triploid blastocyst may have arisen by fusion of a triploid blastocyst with a diploid one. This hypothesis is supported by the observation of a disparity of one between the number of blastocysts and the number of corpora lutea found in this gilt. However, more complex mechanisms involving double fertilizations, fusion of polar bodies, and loss of chromosomes during mitosis cannot be entirely excluded.

The deletion of the short arm of one of the submetacentric chromosomes in one blastocyst is probably best explained as the result of a chromosome break near the centromere during meiosis of one of the gametes with the acentric fragment becoming lost during subsequent cell divisions.

In a review of prenatal mortality in pigs, Hanley (1961) presented figures which demonstrate that about $33 \%$ of the embryos die during the first half of gestation. This study suggests that chromosome abnormalities account for about one-third of the early embryonic mortality in normal pigs although it is possible that some of the abnormalities, especially the deletion, and perhaps the diploid/triploid, might not be lethal. Further studies are planned to ascertain if and when these anomalies exert their effect upon the embryos.

I wish to thank Dr W. C. D. Hare and Dr J. D. Biggers for their valuable suggestions and Miss Eileen P. Hoy for typing the manuscript. The work was supported by U.S.P.H.S. Grants 5 PO6 FR-00120, CA-5097 and 2 Tl GM-957. 


\section{REFERENCES}

CARR, D. H. (1963) Chromosome studies in abortuses and stillborn infants. Lancet, ii, 603.

HANLEY, S. (1961) Prenatal mortality in farm animals. F. Reprod. Fert. 2, 182.

MaFeELY, R. A. (1966) A direct method for the display of chromosomes from early pig embryos. 7. Reprod. Fert. $11,161$.

Perry, J. S. \& Rowlands, I. W. (1962) Early pregnancy in the pig. F. Reprod. Fert. 4, 175. 